\title{
S22 - Perfil de salud integral de estudiantes inmigrantes nicaragüenses en escuelas y colegios de Costa Rica
}

\author{
Natalia Campos-Saborío*, Hilda P. Núñez-Rivas, Ileana Holst-Schumacher, \\ Flory V. Alfaro-Mora, Betty Chacón-Ruiz \\ Universidad Estatal a Distancia de Costa Rica (UNED)
}

*Autor al que se dirige la correspondencia: nataliacampos07@yahoo.com

\section{Resumen}

$\mathrm{E}$ 1 estudio señala las condiciones sociales y culturales que determinan las conductas de riesgo biopsicosocial en los inmigrantes nicaragüenses de 6-22 años de edad que asisten a los centros educativos de Costa Rica. Un total de 202 estudiantes nicaragüenses fueron estudiados a partir de una muestra total de 2,667 niños y jóvenes de 64 centros educativos (40 escuelas y 24 colegios) en Costa Rica. La población nicaragüense tiene mayor riesgo de abandono de los estudios y la repetición y el rezago en sus estudios son significativamente más altos que en los estudiantes de Costa Rica. También tienen una mayor exposición a las drogas lícitas e ilícitas. La prevalencia del consumo de tabaco y marihuana en los nicaragüenses fue tres veces mayor que en los estudiantes de Costa Rica y la prevalencia del consumo de cualquier bebida alcohólica y la inhalación de pegamento duplica a la de los costarricenses. Los jóvenes nicaragüenses se sienten más rechazados en la comunidad en relación con los costarricenses y alrededor de una cuarta parte de la población de Nicaragua ha sentido deseos de morir y el 15,0\% se han auto-lesionado intencionalmente. La edad media de inicio de las relaciones sexuales es de 13.8 años, sin diferencias significativas entre los jóvenes de los dos países. Los jóvenes de ambas poblaciones indicaron que utilizan más el preservativo masculino que la píldora o inyección como métodos anticonceptivos. Más esfuerzos deben hacerse para ofrecer mejores condiciones de vida a los inmigrantes.

Palabras claves: Drogas, violencia, relaciones sexuales, salud mental, alumnos

\section{Abstract}

$\mathrm{T}$ The emphasis of this study is to point out the social and cultural conditions that are determinants of bio-psico-social risk behaviors in the Nicaraguan immigrants from 6-22 years of age who are attending Costa Rican educational centers. A total of 202 Nicaraguan students were studied from a total sample of 2,667 children and youngsters from 64 educational centers ( 40 schools and 24 high schools) all over Costa Rica. The Nicaraguan population has higher risk of abandoning their studies and the repetition and the lag behind years in their studies are significantly higher than in the Costa Rican students. They also have a higher exposure to licit and illicit drugs. The prevalence of smoking tobacco and marijuana in the Nicaraguans is three times higher than in the Costa Rican students and the prevalence of consumption of any alcoholic beverage and sniffing glue doubles that of the Costa Ricans. Nicaraguan youngsters feel more rejected in the community in relation to the Costa Ricans and around a fourth part of the Nicaraguan population has felt desires to die and $15.0 \%$ have done intentional self-injures. The average age of onset of sexual intercourse is 13.8 years, with no significant differences between young people from both countries. Youngsters of both populations indicated that they used more the male condom than the pill or injection as contraceptive methods. More efforts have to be done to offer immigrants better living conditions.

Keywords: Drugs, violence, sexual relations, mental health, students 